\title{
Glutamatergic Agents in the Treatment of Compulsivity and Impulsivity in Child and Adolescent Psychiatry: a Systematic Review of the Literature
}

Konstantin Mechler ${ }^{1}$, Alexander Häge ${ }^{1}$, Nina Schweinfurth ${ }^{1,2}$, Jeffrey C. Glennon³, Rick M. Dijkhuizen ${ }^{4}$, Declan Murphy ${ }^{5}$, Sarah Durston ${ }^{6}$, Steven Williams ${ }^{7}$, Jan K. Buitelaar ${ }^{3}$, Tobias Banaschewski ${ }^{8}$, Ralf W. Dittmann¹, and the TACTICS Consortium

\footnotetext{
Research Group of Paediatric Psychopharmacology, Department of Child and Adolescent Psychiatry and Psychotherapy, Central Institute of Mental Health, Medical Faculty Mannheim, University of Heidelberg, Mannheim, Germany

3 Department of Child and Adolescent Psychiatry and Psychotherapy, Central Institute of Mental Health, Medical Faculty Mannheim, University of Heidelberg, Mannheim, Germany
}

\begin{abstract}
Objective: Research has implicated glutamatergic projections between the various frontal subregions in the pathogenesis of compulsivity and impulsivity. Reducing striatal glutamate release, or antagonising the action of glutamate at its receptors, may therefore represent viable treatment strategies. Several glutamatergic agents with regulatory approval for other indications are available and may be of potentia benefit in the treatment of compulsivity/impulsivity in psychiatric disorders in paediatric patients. Method: This review was performed according to PRISMA guidelines and evaluates available scientific literature concerning the use of glutamatergic agents in these patients, in order to determine their reported effectiveness/efficacy and tolerability/safety. Results: Out of a total of 1,426 publications, 21 trials examining six glutamatergic substances in patients with obsessive-compulsive disorder, autism spectrum disorders, and attention deficit/hyperactivity disorde were included. Conclusions: Trial designs as well as results were heterogeneous and thus comparability was limited. Available data support the hypothesis that glutamatergic agents are of potential value in the treatment of compulsivity/impulsivity in children and adolescents. Based on the data reviewed, memantine and $\mathrm{N}$-acetylcysteine suggest the best risk-benefit profile for future trials. Riluzole should primarily be further investigated in adults. Clinical research of this nature is a key element of the TACTICS Consortium project funded by the European Union (FP7).

Keywords: Glutamate, compulsivity, impulsivity, clinical trials, systematic review
\end{abstract}


Zusammenfassung: Fragestellung: Forschungsergebnisse legen eine wesentliche Beteiligung von glutamatergen Bahnen zwischen den subfrontalen Hirnarealen bei der Pathogenese von Zwanghaftigkeit und Impulsivität nahe. Daher stellen eine Reduktion der Freisetzung von Glutamat im Striatum oder die Antagonisierung von Glutamat am Rezeptor mögliche Behandlungsansätze dar. Diverse glutamaterge Substanzen sind in anderen Indikationsbereichen zugelassen, könnten aber auch von Nutzen bei der Behandlung von Zwanghaftigkeit und Impulsivität im Rahmen kinder- und jugend psychiatrischer Störungsbilder sein. Methodik: Diese Übersichtsarbeit wurde gemäß der PRISMA-Leitlinien erstellt und evaluiert die verfügbare wissenschaftliche Literatur hinsichtlich der Wirksamkeit und Verträglichkeit von glutamatergen Substanzen in der Behandlung von Zwangsstörungen, Autismus-Spektrum-Störungen und Aufmerksamkeitsdefizit-/Hyperaktivitätsstörungen bei Kindern und Jugendlichen. Ergebnisse: Aus einer Gesamtzahl von 1'426 Veröffentlichungen wurden 21 Studien, welche sechs glutamaterge Substanzen in diesen Populationen untersuchten, in die Auswertung eingeschlossen. Schlussfolgerungen: Designs und Ergebnisse der eingeschlossenen Studien zeigten eine deutliche Heterogenität. Deren Vergleichbarkeit war daher eingeschränkt. Die verfügbaren Daten unterstützen die Hypothese, dass glutamaterge Substanzen einen potentiellen Nutzen in der Behandlung von Zwanghaftigkeit und Impulsivität bei Kindern und Jugendlichen haben. Darüber hinaus ließen die Ergebnisse für Memantin und N-Acetylcystein das beste Risiko-Nutzen-Profil für zukünftige klinische Studien bei Kindern und Jugendlichen mit Zwangsstörungen und Autismus-Spektrum-Störungen vermuten. Riluzol sollte zunächst in Studien an erwachsenen Patienten weiter untersucht werden.

Schlüsselwörter: Glutamat, Zwanghaftigkeit, Impulsivität, klinische Studien, systematische Übersichtsarbeit

\section{Introduction}

Compulsivity is a cross-disorder symptom domain observed in several psychiatric disorders, in particular in obsessive-compulsive disorder (OCD), autism spectrum disorders (ASD), and attention deficit/hyperactivity disorder (ADHD). Compulsivity is defined as the repetitive, irresistible urge to perform a certain behaviour, the experience of loss of voluntary control over this intense urge, the diminished ability to delay or inhibit thoughts or behaviours, and the tendency to perform repetitive acts in a habitual or stereotyped manner (Chamberlain, Fineberg, Blackwell, Robbins, \& Sahakian, 2006). This trait is closely linked to impulsivity and addictive behaviour (Chamberlain et al., 2006; Koob \& Le Moal, 1997). Compulsivity-related disorders often commence in childhood and persist into adulthood (Billstedt, Gillberg, \& Gillberg, 2007; Kessler et al., 2005; Lewin, Storch, Geffken, Goodman, \& Murphy, 2006).

Research has implicated frontostriatal neural circuits in the aetiology of compulsivity (Fineberg et al., 2010) and these circuits display a relatively rich glutamatergic receptor density (Monaghan, Yao, \& Cotman, 1985). Neuroimaging studies have confirmed that glutamatergic projections between the various frontal subregions and the striatum play a key role in the regulation of compulsive behaviours in humans (Monaghan et al., 1985; Naaijen, Lythgoe, Amiri, Buitelaar, \& Glennon, 2015; Rosenberg et al., 2000). Modulating striatal glutamate release, or its action at receptors, may therefore represent viable treatment strategies for compulsivity. Javitt reviewed the potential role of glutamate modulators in the treatment of neuropsychiatric disorders and expressed the expectation that progress in development of glutamatergic therapies will accelerate as more and more substances become generally available (Javitt, 2004).

The aim of the currently ongoing multicentre EU-funded TACTICS project (Translational Adolescent and Childhood Therapeutic Interventions in Compulsive Syndromes; http://www.tactics-project.eu/) is to identify the genetic, molecular, and neural factors that underlie the pathogenesis of compulsivity by investigation of animal models and human subjects. A cross-disorder approach enables dissection of trait-related and disordermodifying factors. One further aspect of the TACTICS project is to investigate glutamatergic agents in preclinical animal models as well as in paediatric patients (children and adolescents) in order to assess their effectiveness/efficacy and tolerability/safety. This review evaluates the available literature on the effectiveness/efficacy and tolerability/safety of glutamatergic agents in paediatric patients suffering from three disorders that share the symptom domain of compulsivity and impulsivity as an integral part of their psychopathology.

\section{Obsessive-Compulsive Disorder}

Obsessive-compulsive disorder (OCD) typically manifests in late childhood and affects $0.25 \%$ to $4 \%$ of children and adolescents and $2.5 \%$ of the adult population worldwide (Douglass, Moffitt, Dar, McGee, \& Silva, 1995; Flament et al., 1988; Heyman et al., 2001; Nestadt et al., 2009). OCD is characterised by repetitive thoughts, impulses or images (obsessions) and/or repetitive behaviours or mental acts (compulsions) (American Psychiatric 
Association, 2013). Symptoms lead to a pronounced reduction in quality-of-life and an increase the risk of suicide (Hollander et al., 1996; Kamath, Reddy, \& Kandavel, 2007). Current research on aetiology and pharmacological treatment of OCD is inconclusive (Lewin et al., 2006; Mancuso, Faro, Joshi, \& Geller, 2010; Abdel-Ahad \& Kazour, 2013). Recent studies suggest that OCD is characterised by abnormalities of the cortico-striato-thalamocortical (CSTC) circuitry (Brennan, Rauch, Jensen, \& Pope, 2013; Lewin et al., 2006). Also, several authors have hypothesised that abnormalities in glutamate neurotransmission and homeostasis, particularly in the CSTC circuitry, contribute to the disorder (Carlsson, 2000; Carlsson, 2001; Chakrabarty, Bhattacharyya, Christopher, \& Khanna, 2005; Rosenberg \& Hanna, 2000; Ting \& Feng, 2008).

\section{Autism Spectrum Disorders}

Autism spectrum disorders (ASD) or pervasive developmental disorders (PDD) in a broader sense are heterogeneous neurodevelopmental syndromes that share a characteristic dyad of deficits in social interaction and communication, as well as restricted, repetitive, and stereotyped patterns of behaviour, interests, and activities as core symptoms (American Psychiatric Association, 2013). Core symptom-specific pharmacological interventions are scarce and substances like antipsychotics or psychostimulants are mostly used to control co-morbidities and co-occurring symptoms such as irritability, inattention, impulsivity, and hyperactivity (Parellada et al., 2014). Recent studies in both animal models of monogenetic ASD (de Vrij et al., 2008; Gantois et al., 2013; Pop et al., 2014; Silverman, Tolu, Barkan, \& Crawley, 2010) and small cohort pilot studies (Berry-Kravis et al., 2006; Jacquemont et al., 2011) show promising effects of glutamatergic compounds on stereotypic behaviour and other core symptoms (Erickson et al., 2011; Erickson et al., 2013). There is growing evidence for glutamatergic dysregulation/balance in the broader autistic spectrum (Bristot Silvestrin et al., 2013; Carlsson, 1998; McDougle, Erickson, Stigler, \& Posey, 2005).

\section{Fragile X Syndrome}

The X-linked genetic disorder fragile X syndrome (FXS) is the most common inherited cause of mental retardation and patients show wide variations in psychiatric symptoms (Garber, Visootsak, \& Warren, 2008; Hersh \& Saul, 2011; Sourial, Cheng, \& Doering, 2013). These symptoms include compulsive behaviours (Hall, Lightbody, \& Reiss,
2008; Wolff, Hazlett, Lightbody, Reiss, \& Piven, 2013). FXS is suspected to be the underlying cause for autistic symptoms in approximately $5 \%$ of cases diagnosed with autism (Budimirovic \& Kaufmann, 2011; McLennan, Polussa, Tassone, \& Hagerman, 2011). Research has demonstrated that many fragile $\mathrm{X}$ phenotypes are attributable to an interplay between FMRP and glutamate signalling at the synapse (Sourial et al., 2013). Preclinical studies have generated promising findings concerning the therapeutic value of glutamate receptor blockers in FXS (Hagerman, Lauterborn, Au, \& Berry-Kravis, 2012; Pop et al., 2014). A small number of published studies have evaluated glutamatergic agents in clinical samples (Erickson et al., 2011).

\section{Attention Deficit/ Hyperactivity Disorder}

Attention deficit/hyperactivity disorder (ADHD) affects approximately $5 \%$ of all school-aged children worldwide and is thus among the most common of all childhood psychiatric disorders (Polanczyk \& Rohde, 2007; Polanczyk, Willcutt, Salum, Kieling, \& Rohde, 2014). ADHD is characterised by impulsive, hyperactive, and inattentive behaviours (American Psychiatric Association, 2013; Biederman \& Faraone, 2005). ADHD has been associated with reduced health-related quality of life (Klassen, Miller, \& Fine, 2004; Virring, Lambek, Jennum, Møller, Thomsen 2017). Research has identified associations between ADHD and changes in frontostriatal circuits (Durston, van Belle, \& de Zeeuw, 2011; de Zeeuw, Mandl, Hulshoff Pol, van Engeland, \& Durston, 2012). Comparisons of ADHD and OCD have revealed both commonalities and disorder-specific differences in terms of frontostriatal circuitry (Rubia et al., 2010; Rubia, Cubillo, Woolley, Brammer, \& Smith, 2011). Firstly, studies of dopamine and of glutamatergic systems have associated the NMDA receptor with the cognitive memory and attention deficits observed in ADHD (Kotecha et al., 2002). Secondly, genetic research has identified an association between ADHD and polymorphisms in the N-methyl-D aspartate glutamate receptor 2A gene (Turic et al., 2004). Thirdly, atomoxetine acts as an NMDA receptor blocker in clinically relevant concentrations (Ludolph et al., 2010). Fourthly, a neuroimaging study of four children with ADHD revealed pronounced glutamatergic changes in the striatum following treatment with either methylphenidate or atomoxetine (Carrey, MacMaster, Sparkes, Khan, \& Kusumakar, 2002). Lastly, significant differences in striatal glutamate concentration between adults with ADHD and matched controls were reported (Horder et al., 2013). Modulation of glutamate may thus represent a promising therapeutic strategy. 


\section{Glutamatergic Agents in Neuropsychiatric Disorders}

The trials included in the present review investigated a total of six glutamatergic agents. They are briefly characterized in the following:

\section{D-Cycloserine}

D-cycloserine $((R)$-4-amino-1,2-oxazolidin-3-one) is an effective inhibitor of alanine racemase (Lambert \& Neuhaus, 1972) and a partial agonist at the glycine site of neuronal NMDA receptors (Prosser \& de Carvalho, 2013). Dcycloserine is authorised in Europe and the USA as a second-line therapy for tuberculosis (Ramachandran \& Swaminathan, 2015).

\section{Memantine}

Memantine (3,5-dimethyladamantan-1-amine) antagonises the action of glutamate at its receptors, most likely mediated principally through the voltage-dependent blockade of current flow through NMDA receptor channels (Johnson \& Kotermanski, 2006; Parsons, Stoffler, \& Danysz, 2007). Memantine is authorised in Europe and the USA for the treatment of moderate to severe Alzheimer's disease (European Medicines Agency, 2015b; Food and Drug Administration, 2010).

\section{Minocycline}

Minocycline ((4S,4AS,5ar,12as)-4,7-bis(dimethylamino)3,10,12,12a-tetrahydroxy-1,11-dioxo-1,4,4a,5,5a,6,11,12aoctahydrotetracene-2-carboxamide), a second generation tetracycline antibiotic agent, has not only proven to act bacteriostatically against a broad spectrum of germs, it also possesses anti-inflammatory and anti-oxidative properties. Recent research found minocycline to reduce glutamate excitotoxicity and augment neurogenesis (Dean, Data-Franco, Giorlando, \& Berk, 2012).

\section{Modafinil}

Modafinil (( \pm )-2-(benzhydrylsulfinyl)acetamide) increases vigilance and is approved in the USA for the treatment of narcolepsy, obstructive sleep apnoea, and shift work disorder (Food and Drug Administration, 2015). Although its precise mechanism of action remains unclear, research suggests that modafinil stimulates the release of glutamate in both the hippocampus and the thalamus (Gerrard \& Malcolm, 2007).

\section{$\mathrm{N}$-Acetylcysteine}

$\mathrm{N}$-acetylcysteine (2-acetamido-3-sulfanylpropanoic acid) is a derivative of cysteine and is authorised in Europe and the USA for the treatment of paracetamol (acetaminophen) overdose and as a mucolytic agent (Food and Drug
Administration, 2006; Marzullo, 2005; U.S. National Library of Medicine, 2014).

\section{Riluzole}

Riluzole (2-amino-6-trifluoromethoxy benzothiazole) is a benzothiazole with neuroprotective, anticonvulsant, anxiolytic, and anaesthetic properties (Kretschmer, Kratzer, \& Schmidt, 1998). Its effects are mediated by blockade of glutamate transmission, the stabilisation of sodium channels, and blockage of gamma-aminobutyric acid reuptake. Riluzole mainly acts on glutamate transmission. In vitro, this is mediated predominately by N-methyl-D-aspartate (NMDA) receptor-linked processes. Riluzole is authorised in Europe and the USA for the treatment of amyotrophic lateral sclerosis (European Medicines Agency, 2015a; Food and Drug Administration, 2009).

\section{Methods}

This review was performed according to the guidelines set forth by the PRISMA statement for systematic reviews and meta-analyses (Moher et al. 2009).

\section{Search Strategy}

The PubMed library (http://www.ncbi.nlm.nih.gov/ pubmed) was searched for English language studies with the key words "glutamatergic" in combination with, "Attention deficit/hyperactivity disorder", "Autism Spectrum Disorder", "Pervasive developmental disorder", "Fragile X Syndrome" or "Obsessive-compulsive disorder", respectively. For this report, we focused primarily on studies that examined substance effects in patients with OCD, ASD/PDD, FXS, and ADHD. However, we also included studies with related disorders, e.g. trichotillomania (TTM) or nail biting. Relevant articles were also selected from reference lists. In order to create a most accurate and up-todate database, we also included abstracts from major international research conferences. The last search was conducted on 19 November 2014 and included all studies published by that date.

\section{Selection of Studies}

All studies resulting from the search strategy described, were reviewed for eligibility by title and/or abstract by two of the authors. Any disagreement between reviewers was resolved through discussion within our research group. Clinical trials were included if they: (1) investigated gluta- 
matergic compounds in OCD, ASD/PDD/FXS or ADHD, (2) had a randomized controlled double-blind trial (RCT) or open-label trial (OLT) design, and (3) included paediatric patients (younger than 18 years, exclusively or partially), regardless of sample size.

\section{Data Extraction}

Data were extracted from full-text articles, if available, and included characteristics of the reported study (design, duration), of the study population (numbers of subjects participating in the trial, completing the trial and for each group, mean age and age range, gender ratio) and of the medication investigated (substance, daily dose). Primary outcome measures (as stated by the authors), mean changes in these measures, and results from statistical tests (pre-post-effect comparison in OLTs and group comparisons in RCTs) were also recorded. If provided, pvalues from analyses of drug versus placebo group differences post-treatment, group main effect and interaction main effect as well as definitions and rates of response were also extracted. To improve comparability of the reviewed studies, effect sizes as a dimensionless measure of effectiveness/efficacy were collected, or where possible, derived. F-values from variance analyses were converted into Cohen's d values (Cohen, 1988; Thalheimer \& Cook, 2002). By convention, a value of $d$ higher than 0.2 is considered small, higher than 0.5 medium, and higher than 0.8 large (Cohen, 1988).

If definition of response and responder rates were provided, the number needed to treat (NNT) was calculated, which is defined as the average number of patients needed to undergo a certain treatment to allow for one patient to successfully respond to this treatment (Laupacis, Sackett, \& Roberts, 1988). Mathematically, the NNT is the inverse of the difference in responder rates in per cent. In order not to overestimate treatment effects, the NNT was always rounded up to the next whole number (McQuay \& Moore, 1997).

To further assess tolerability and safety of the glutamatergic agents investigated in this review, rates and descriptions of serious adverse events (SAEs) and adverse events (AEs) were extracted. Percentages for adverse events were calculated for the combined study populations in each of the groups "active treatment", "placebo", and "open-label", separately. Although some publications and research conference abstracts did not disclose a complete list of adverse events and, e.g., only listed the three most frequent adverse events, it was preferred to include all accessible data to minimize the risk of missing potentially harmful adverse events in this review. Rates for all SAEs and AEs that were reported for at least $5 \%$ of patients in one of the study groups are shown in the respective online supplementary tables S1-S6 (ESM 1-ESM 6). Numbers were included in this review exactly as provided by the respective publications.

\section{Results}

\section{Study Selection}

1,426 articles were identified using the search strategy described above. After exclusion of articles that did not meet inclusion criteria (see above), 18 studies remained. For details of the study selection process see the flowchart (Figure 1). After adding three recent research conference abstracts, a total of 21 studies investigating six glutamatergic drugs were included in this review. These consisted of 12 RCTs and 9 OLTs. One trial was a randomized doubleblind, placebo-controlled withdrawal trial (Hardan, 2014). Four of the OLTs included both paediatric and adult patients. None of the RCTs used an active control arm. In 14 of the included trials, the investigated drug was used as an augmentation of a pre-existing medication and/or psychotherapy. For two trials, published as research conference abstracts, only approximate numbers of patients in each of

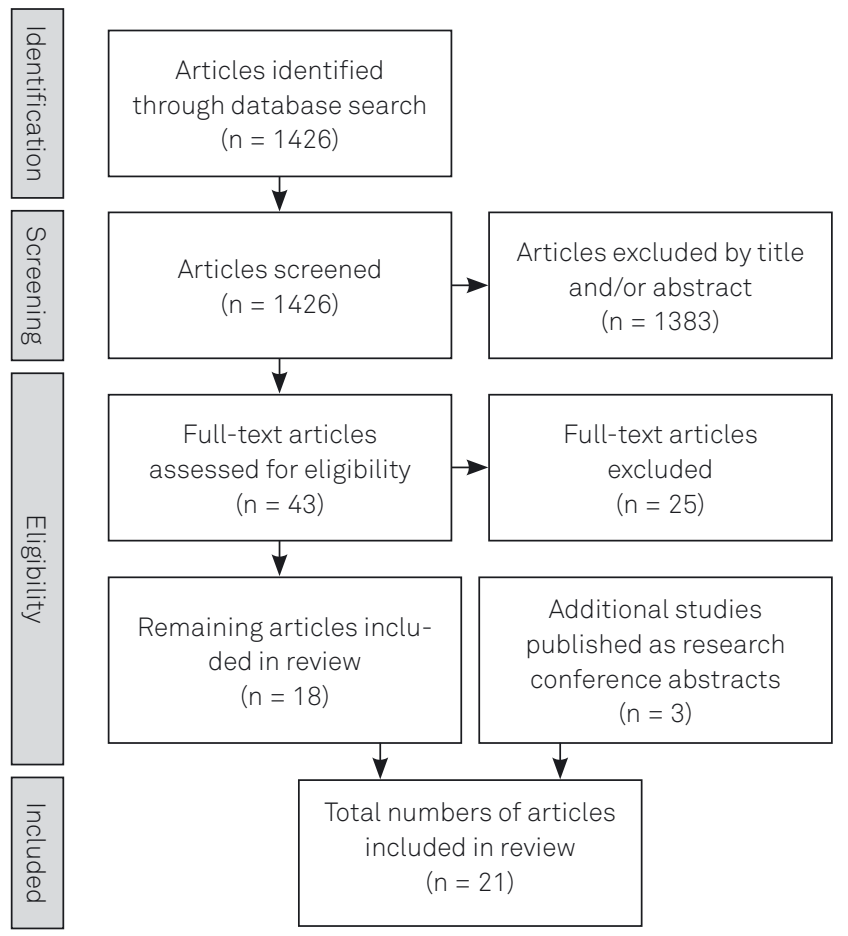

Figure 1. Flow diagram depicting the process of study selection for the present systematic review according to the guidelines set forth by the PRISMA statement for systematic reviews and meta-analyses (adapted from: (Moher et al., 2009)). 
the study groups were provided by the authors. Six trials ( 5 RCTs, 1 OLT) included patients with OCD, trichotillomania or nail-biting, 13 trials (6 RCTs, 7 OLTs) patients with ASD, PDD or FXS, and two trials (1 RCT, 1 OLT) patients with ADHD. One publication summarized three clinical trials (modafinil in ADHD) by reporting a pooled analysis of all three studies (Wigal, Biederman, Swanson, Yang, \& Greenhill, 2006). Accordingly, this publication was regarded as one study throughout this review.

Characteristics of all reviewed studies are shown in Table 1 for RCTs and Table 2 for OLTs, respectively. Results for each substance are presented in alphabetical order.

\section{D-Cycloserine}

\section{Treatment Effects (Tables 1 and 2)}

One RCT in 30 paediatric patients with OCD found medium treatment effects in favour of d-cycloserine, but this difference between the treatment and control group did not reach statistical significance (Storch et al., 2010). Another RCT investigated d-cycloserine as augmentation of behaviour therapy in OCD. Statistically significant improvements in OCD symptoms were observed both in the treatment and the placebo group, yet significant group differences could only be shown for time-to-response at the post-treatment evaluation. At the one- and three-month follow-up, no significant differences were observed (Farrell et al., 2013). D-cycloserine as monotherapy in ASD was evaluated in 12 patients with an open-label study design. Seven patients showed an improvement on the social avoidance subscale of the Aberrant Behavior ChecklistCommunity (ABC-C) (Aman, Burrow, \& Wolford, 1995). Furthermore, $40 \%$ of patients were reported as having responded to treatment, defined as a score of less than or equal to 2 on the Clinical Global Impression - Improvement (CGI-I) (Guy, 1976) scale (Posey et al., 2004).

\section{Adverse Events (Table S1)}

Very few adverse events (AEs) and no serious adverse events (SAEs) were reported for d-cycloserine in the trials reviewed here.

\section{Memantine}

\section{Treatment Effects (Tables 1 and 2)}

A first RCT investigated memantine augmentation of risperidone treatment in children with ASD. The group receiving memantine showed statistically significant better improvement in the subscales 'irritability, stereotypic behaviour and hyperactivity' of the ABC-C compared to the placebo group (Ghaleiha, Asadabadi, et al., 2013). Three interconnected trials regarding memantine in ASD/PDD were presented at the Annual Meeting of the American Psychiatric Association (APA) 2014 (at the time of submission of this review only abstracts were available): First, a very large $(n=906)$ OLT in paediatric ASD assessed treatment outcome by administration of the Social Responsiveness Scale (SRS) (Constantino et al., 2003). A total of $59.6 \%$ of patients responded to memantine therapy (Melmed, 2014). In a second study, $n=479$ of those subjects that had been confirmed as responders to memantine treatment before (no exact definition provided), subsequently completed a 12 -week withdrawal trial with a double-blind, placebo-controlled design and two memantine dosing possibilities (full dose continuation or $\leq 50 \%$ dose). Loss of therapeutic response (assessed by SRS) was around $65 \%$ in all three groups with no statistically significant group differences, a result not interpreted by the authors in the available abstract (Hardan, 2014). The third trial with 121 patients started with a double-blind, placebo-controlled phase and included an open-label extension phase. Both groups showed statistically significant improvement in SRS scores by week 12 with no statistically significant group differences (Hendren, 2014).

An OLT in 14 ASD patients reported statistically significant improvements for the ABC-C total score as well as the subscales ,hyperactivity', ,impulsivity', and ,stereotypical behaviour' (Owley et al., 2006). A second OLT found statistically significant improvements measured by the CGIImprovement scale plus in the domains 'language, behaviour, and self-stimulatory behaviours' (Chez et al., 2007). A similar third OLT in 18 ASD patients demonstrated statistically significant improvements for the ABC-C subscale 'hyperactivity' only (Erickson et al., 2007).

An open-label, monotherapy, dose-finding, eight-week pilot trial investigated 16 paediatric outpatients with ADHD (combined subtype). Clinical improvement was assessed using the parent-completed ADHD Rating Scale-IV (DuPaul, Power, Anastopoulos, \& Reid, 1998) and the investigator-rated Clinical Global Impression - Severity (CGI-S) (Guy, 1976) scale. Only four patients completed the trial (Findling et al., 2007).

\section{Adverse Events (Table S2)}

Six SAEs $(0.5 \%)$ were reported for the total of 1,106 patients participating in six OLTs. All six were reported for the same OLT and were not further specified in the respective publication (Melmed, 2014). Mild adverse events were recorded in almost all trials but remained transient or were common in placebo-treated groups as well. Except for headache (7.2\%) and nasopharyngitis (5.3\%), all of the AEs occurred less frequently than in $5 \%$ of patients in one of the study groups. 


\section{Minocycline}

\section{Treatment Effects (Tables 1 and 2)}

Only studies investigating minocycline in patients with fragile X syndrome (FXS) were found. One RCT included paediatric patients only (Leigh et al., 2013), whereas two OLTs included both adult and paediatric patients (Paribello et al., 2010; Utari et al., 2010). In the RCT, 55 patients completed the trial, which incorporated a crossover design and used minocycline vs. placebo as an augmentation therapy. Ratings on the CGI-I scale differed statistically significantly between groups in favour of the treatment group (Leigh et al., 2013).

Augmentation of various pharmacological treatments with minocycline was investigated in 20 FXS patients in one OLT; the primary outcome measure was the ABC-C total score. A statistically significant reduction was noted after the treatment phase of eight weeks (Paribello et al., 2010).

Utari and colleagues retrospectively evaluated the minocycline treatment of 50 FXS patients. Using a self-developed parent-questionnaire with a 5-point Likert scale to measure change in different domains, $54 \%$ of patients were reported to have improved in the domain language, $30 \%$ in anxiety/moodiness, $44 \%$ in communication, $20 \%$ in impulsivity, $50 \%$ in attention, and $12 \%$ in hyperactivity (worsened in 14\%) (Utari et al., 2010).

\section{Adverse Events (Table S3)}

While no SAEs were reported for any of the three trials included, one RCT investigating minocycline in FXS reported comparably high rates of mild AEs, predominantly gastrointestinal difficulties, both for the treatment and the placebo group. Both gastrointestinal distress and headache were more common in the placebo than the treatment group. Apart from that, AE rates were similar in both groups and ranged from $3.0 \%$ to $45.5 \%$ (Leigh et al., 2013). Combining reports from the two OLTs, gastrointestinal distress occurred as an $\mathrm{AE}$ in $25.7 \%$ of patients (Paribello et al., 2010; Utari et al., 2010).

\section{Modafinil}

\section{Treatment Effects (Tables 1 and 2)}

The publication by Wigal and colleagues reported a comprehensive analysis of the pooled data from three paediatric trials $(\mathrm{n}=638)$. In all three studies, patients with ADHD received modafinil as monotherapy in a double-blind, placebo-controlled design. The authors described a statistically significant reduction of symptom severity as measured by the ADHD-RS IV, ADHD index score (measured by the revised Conners' Parent Rating Scales (CPRS-R) (Conners, Sitarenios, Parker, \& Epstein, 1998), CGI-I, as well as oppo- sitional behaviour, cognitive problems/inattention, and hyperactivity as assessed by CPRS-R. Regarding core symptomatology improvements in ADHD, measured by ADHDRS-IV, an effect size of 0.69 (Cohen's d, group main effect) for the treatment with modafinil compared to placebo was calculated. In total, $46 \%$ of patients in the treatment group were classified as responders (defined as a score of less than or equal to 2 on the CGI-I scale) vs. $18 \%$ in the placebo group which translates to a NNT of 4 (Wigal et al., 2006).

\section{Adverse Events (Table S4)}

Eight SAEs were reported for the 635 patients included in the analysis of three pooled paediatric trials (Wigal et al., 2006). None were fatal and all occurred in the group receiving modafinil $(n=420)$.

\section{$\mathrm{N}$-Acetylcysteine}

\section{Treatment Effects (Tables 1 and 2)}

Two RCTs in paediatric nail biting and trichotillomania, respectively, reported no statistically significant effects of $\mathrm{N}$-acetylcysteine on nail length or hair pulling compared to placebo. In both trials, $\mathrm{N}$-acetylcysteine was used as an augmentation of different medications over a period of 12 and eight weeks, respectively (Bloch, Panza, Grant, Pittenger, \& Leckman, 2013; Ghanizadeh, Derakhshan, \& Berk, 2013). In the trial reported by Ghanidzadeh et al., only 25 out of 49 patients completed the trial with most of them not showing up for further study visits. In a third RCT, including 31 paediatric patients with ASD, augmentation of risperidone therapy with $\mathrm{N}$-acetylcysteine was reported to be superior compared to placebo augmentation on the 'irritability' subscale score of the ABC-C. This treatment effect was statistically significant and showed an effect size of 0.83 (Cohen's d, drug versus placebo post-treatment; (Ghanizadeh \& Moghimi-Sarani, 2013).

\section{Adverse Events (Table S5)}

No SAEs were reported for the three included trials. Mild AEs occurred (e.g., drowsiness, diarrhoea, nausea, cough, etc., approximately $10-20 \%$ each). Rates for these AEs were generally higher in the group receiving $\mathrm{N}$-acetylcysteine compared to the placebo group, except for fatigue and nausea, which were more common in the placebo group.

\section{Riluzole}

\section{Treatment Effects (Tables 1 and 2)}

One RCT investigating augmentation of risperidone with riluzole or placebo in 49 children with ASD/PDD suggested stronger effects of riluzole versus placebo on the 


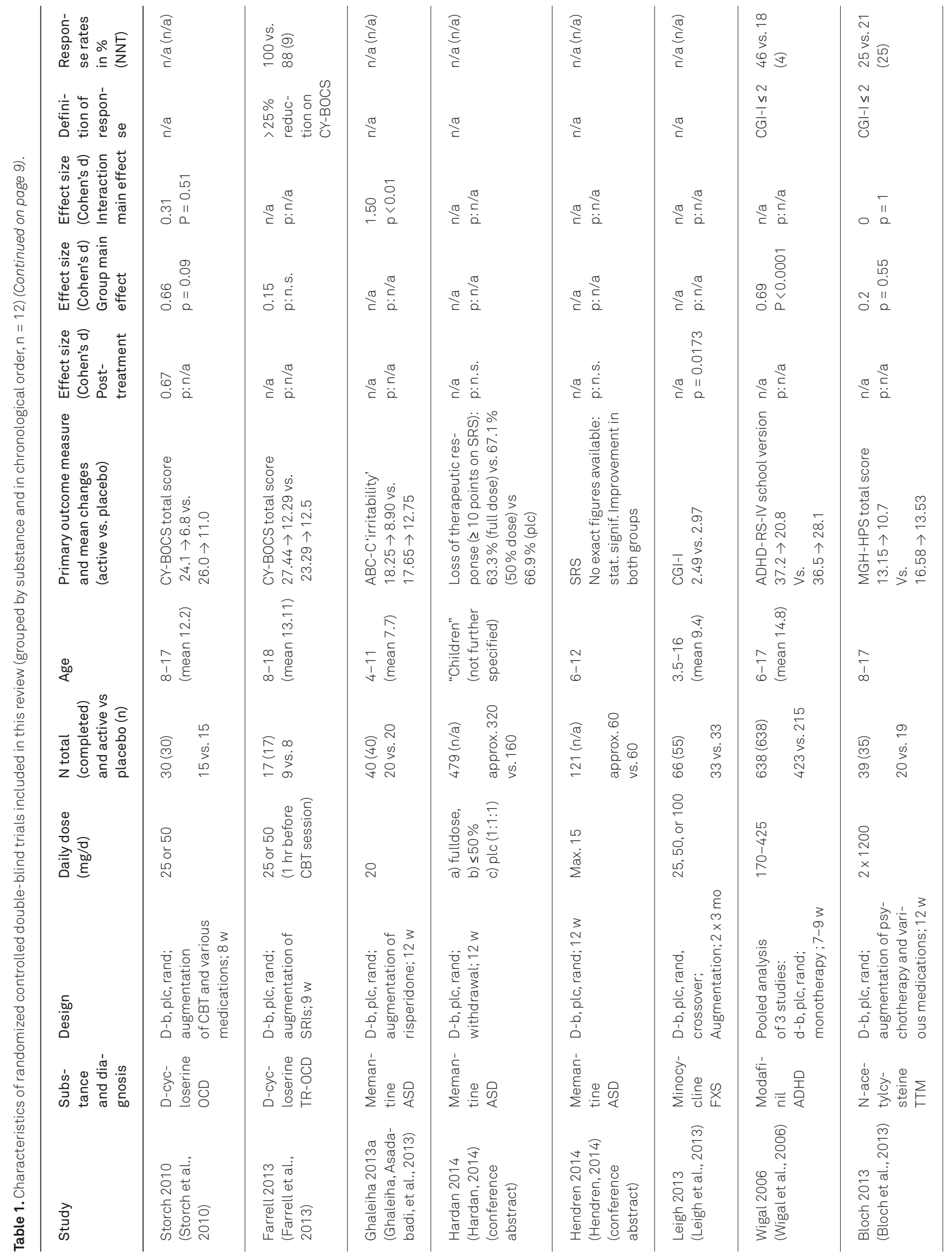




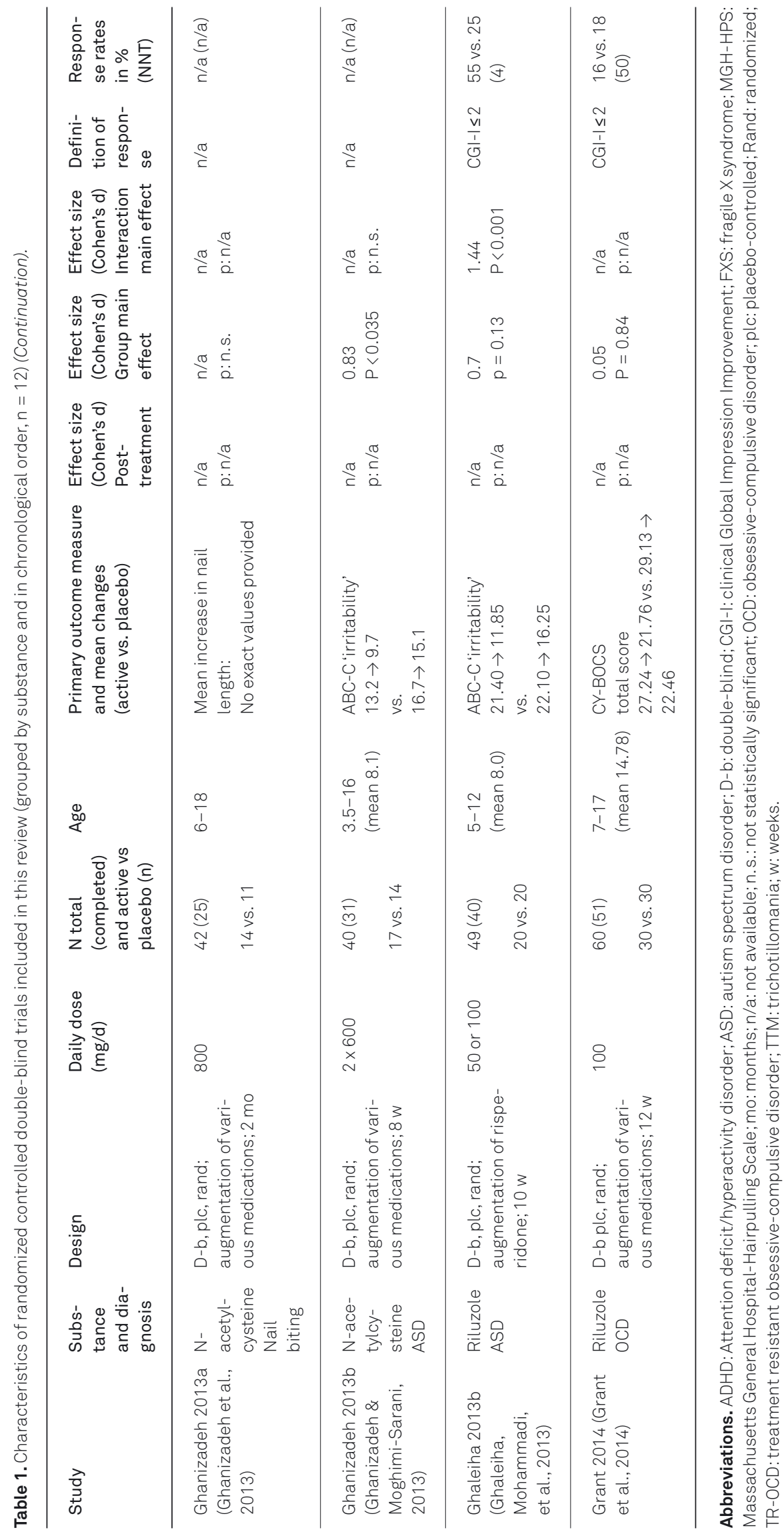


Table 2. Characteristics of open-label trials included in this review (grouped by substance and in chronological order, $n=9$ ).

\begin{tabular}{|c|c|c|c|c|c|c|c|c|c|}
\hline Study & $\begin{array}{l}\text { Subs- } \\
\text { tance } \\
\text { and di- } \\
\text { agnosis }\end{array}$ & Design & $\begin{array}{l}\text { Daily } \\
\text { dose } \\
(\mathrm{mg} / \mathrm{d})\end{array}$ & $\begin{array}{l}\mathrm{N} \text { total } \\
\text { (comple- } \\
\text { ted) }\end{array}$ & Age & $\begin{array}{l}\text { Primary outcome measure } \\
\text { and mean changes }\end{array}$ & $\begin{array}{l}\text { p-value for pre- } \\
\text { post change in } \\
\text { primary out- } \\
\text { come measure }\end{array}$ & $\begin{array}{l}\text { Defini- } \\
\text { tion of } \\
\text { respon- } \\
\text { se }\end{array}$ & $\begin{array}{l}\text { Res- } \\
\text { ponse } \\
\text { rate in } \\
\%\end{array}$ \\
\hline $\begin{array}{l}\text { Posey } 2004 \\
\text { (Posey et } \\
\text { al., 2004) }\end{array}$ & $\begin{array}{l}\text { D-cyc- } \\
\text { loserine } \\
\text { ASD }\end{array}$ & $\begin{array}{l}\text { Open-label; } \\
\text { monotherapy; } \\
\text { ascending dosage; } \\
8 \mathrm{w}\end{array}$ & $\begin{array}{l}0.7,1.4 \\
\text { and } \\
2.8 \mathrm{mg} / \\
\mathrm{kg} \mathrm{BW}\end{array}$ & $12(10)$ & $5-27$ & $\begin{array}{l}\text { ABC-C } \\
\text { Social avoidance subscale: } \\
14 \rightarrow 5.8\end{array}$ & 0.02 & $C G I-I \leq 2$ & 40 \\
\hline $\begin{array}{l}\text { Owley } 2006 \\
\text { (Owley et } \\
\text { al., 2006) }\end{array}$ & $\begin{array}{l}\mathrm{Me}^{-} \\
\text {mantine } \\
\text { PDD }\end{array}$ & $\begin{array}{l}\text { Open-label; } \\
\text { augmentation } \\
\text { of various medi- } \\
\text { cations; } 8 \text { w }\end{array}$ & $\begin{array}{l}0.4 \mathrm{mg} / \\
\mathrm{kg} \mathrm{BW}\end{array}$ & $14(12)$ & $\begin{array}{l}3-12 \\
\text { (mean } \\
7.8)\end{array}$ & $\begin{array}{l}\text { ABC-C } \\
\text { Total score: } 52.7 \rightarrow 26.9 \\
\text { 'Hyperactivity' subscale: } \\
22.2 \rightarrow 11.0 \\
\text { 'Irritability' subscale: } 11.5 \rightarrow 6.3 \\
\text { 'Stereotypy' subscale: } 3.9 \rightarrow 2.3\end{array}$ & Total: 0.001 & $C G I-I \leq 2$ & 0 \\
\hline $\begin{array}{l}\text { Chez } 2007 \\
\text { (Chez et al., } \\
\text { 2007) }\end{array}$ & $\begin{array}{l}\text { Me- } \\
\text { mantine } \\
\text { ASD }\end{array}$ & $\begin{array}{l}\text { Open-label; } \\
\text { augmentation } \\
\text { various medi- } \\
\text { cations; } 1-20 \text { mo }\end{array}$ & $2.5-30$ & $\begin{array}{l}151 \\
(124)\end{array}$ & $\begin{array}{l}2.6- \\
26.3 \\
\text { (mean } \\
9.31 \text { ) }\end{array}$ & $\begin{array}{l}\text { CGI-I } \\
\text { Significant improvements re- } \\
\text { ported for language, behaviour } \\
\text { and self-stimulatory behavi- } \\
\text { ours. }\end{array}$ & $\mathrm{n} / \mathrm{a}$ & $\mathrm{n} / \mathrm{a}$ & $n / a$ \\
\hline $\begin{array}{l}\text { Erickson } \\
2007 \\
\text { (Erickson } \\
\text { et al., 2007) }\end{array}$ & $\begin{array}{l}\text { Me- } \\
\text { mantine } \\
\text { PDD }\end{array}$ & $\begin{array}{l}\text { Open-label; retros- } \\
\text { pective chart re- } \\
\text { view; augmentation } \\
\text { of various medi- } \\
\text { cations; } 1.5-56 \mathrm{w}\end{array}$ & $2.5-20$ & $18(18)$ & $\begin{array}{l}6-19 \\
(\text { mean } \\
11.4)\end{array}$ & $\begin{array}{l}\text { ABC-C } \\
\text { Hyperactivity subscale: } \\
23.17 \rightarrow 16.33 \\
\text { No significant changes i n } \\
\text { other ABC subscales. }\end{array}$ & 0.03 & $C G|-| \leq 2$ & 61 \\
\hline $\begin{array}{l}\text { Findling } \\
2007 \\
\text { (Findling et } \\
\text { al., 2007) }\end{array}$ & $\begin{array}{l}\text { Me- } \\
\text { mantine } \\
\text { ADHD }\end{array}$ & $\begin{array}{l}\text { Open-label, } \\
\text { dose-finding; } \\
\text { monotherapy; } 8 \text { w }\end{array}$ & 10 or 20 & $16(4)$ & $\begin{array}{l}6-12 \\
\text { (mean } \\
8.1)\end{array}$ & $\begin{array}{l}\text { ADHD-IV total score: } \\
\text { a) } 10 \mathrm{mg}: 44.6 \rightarrow 40.9 \\
\text { b) } 20 \mathrm{mg}: 41.9 \rightarrow 32.9\end{array}$ & $\mathrm{n} / \mathrm{a}$ & $\mathrm{n} / \mathrm{a}$ & $n / a$ \\
\hline $\begin{array}{l}\text { Melmed } \\
2014 \text { (Mel- } \\
\text { med, 2014) } \\
\text { (conference } \\
\text { abstract) }\end{array}$ & $\begin{array}{l}\text { Me- } \\
\text { mantine } \\
\text { ASD }\end{array}$ & $\begin{array}{l}\text { Open-label; } \\
\text { up to } 48 \text { w }\end{array}$ & $\begin{array}{l}\text { Max: } 15 \\
\text { Weight- } \\
\text { based }\end{array}$ & $906(n / a)$ & $6-12$ & $\begin{array}{l}\text { SRS } \\
\mathrm{n} / \mathrm{a}\end{array}$ & $\mathrm{n} / \mathrm{a}$ & $\begin{array}{l}\text { No ex- } \\
\text { act de- } \\
\text { finition, } \\
\text { "based } \\
\text { on SRS" }\end{array}$ & $59.6 \%$ \\
\hline $\begin{array}{l}\text { Paribello } \\
2010 \\
\text { (Paribello } \\
\text { et al., 2010) }\end{array}$ & $\begin{array}{l}\text { Minocy- } \\
\text { cline } \\
\text { FXS }\end{array}$ & $\begin{array}{l}\text { Open-label; } \\
\text { augmentation } \\
\text { of various medi- } \\
\text { cations; } 8 \text { w }\end{array}$ & $\begin{array}{l}\text { a) } 2 \times 50 \\
\text { b) } 2 \times 100\end{array}$ & $20(19)$ & $\begin{array}{l}13-32 \\
\text { (mean } \\
18)\end{array}$ & $\begin{array}{l}\text { ABC-C total score } \\
70.26 \rightarrow 38.90\end{array}$ & $<0.001$ & $\mathrm{n} / \mathrm{a}$ & $n / a$ \\
\hline $\begin{array}{l}\text { Utari } 2010 \\
\text { (Utari et al., } \\
\text { 2010) }\end{array}$ & $\begin{array}{l}\text { Minocy- } \\
\text { cline } \\
\text { FXS }\end{array}$ & $\begin{array}{l}\text { Retrospective } \\
\text { evaluation; } \\
\text { Monotherapy; } \\
2 \text { w-20 mo }\end{array}$ & $25-200$ & $50(50)$ & $\begin{array}{l}0.3- \\
25 \\
(13.3)\end{array}$ & $\begin{array}{l}\text { 5-point Likert scale, } \\
\text { investigator rated } \\
\text { Improvement in } \\
\text { - Language (54\%) } \\
\text { - Anxiety/Moodiness (30\%) } \\
\text { - Communication (44\%) } \\
\text { - Impulsivity (20\%) } \\
\text { - Attention (50\%) } \\
\text { - Hyperactivity (12\%, } \\
\text { worsened in 14\%) }\end{array}$ & $\mathrm{n} / \mathrm{a}$ & $\mathrm{n} / \mathrm{a}$ & $n / a$ \\
\hline $\begin{array}{l}\text { Grant } 2007 \\
\text { (Grant et } \\
\text { al., 2007) }\end{array}$ & $\begin{array}{l}\text { Riluzole } \\
\text { OCD }\end{array}$ & $\begin{array}{l}\text { Open-label; } \\
\text { augmentation } \\
\text { of various medi- } \\
\text { cations; } 12 \mathrm{w}\end{array}$ & $50-120$ & $6(6)$ & $\begin{array}{l}8.3- \\
16.4 \\
\text { (mean } \\
14.4 \text { ) }\end{array}$ & $\begin{array}{l}\text { CY-BOCS total score } \\
28.8 \rightarrow 17.7\end{array}$ & $\mathrm{n} / \mathrm{a}$ & $\begin{array}{l}\text { CY- } \\
\text { BOCS } \geq \\
30 \% \downarrow\end{array}$ & $67 \%$ \\
\hline
\end{tabular}

Abbreviations. ABC-C: Aberrant Behavior Checklist-Community; ADHD: attention deficit/hyperactivity disorder; ASD: autism spectrum disorder; CGI-I: Clinical Global Impression Improvement; CY-BOCS: Children's Yale-Brown Obsessive Compulsive Scale; FXS: fragile X syndrome; mo: months; n/a: not available; n.s.: not statistically significant; OCD: obsessive-compulsive disorder; PDD: pervasive developmental disorder; SRS: Social Responsiveness Scale; TR-OCD: treatment resistant obsessive-compulsive disorder;TTM: trichotillomania; w: weeks. 
ABC-C subscales 'irritability, stereotypy, and hyperactivity' but none of these reached statistical significance. Interestingly, $55 \%$ of patients in the active treatment group versus $25 \%$ in the placebo group were classified as responders (defined as a score of less than or equal to 2 on the CGI-I scale) which translates to a NNT of 4 (Ghaleiha, Mohammadi, et al., 2013).

Grant et al. recently published a placebo-controlled phase II RCT of riluzole in paediatric OCD. Sixty patients received riluzole for 12 weeks as an augmentation of various medications. No statistically significant group differences could be shown for the outcome measures of CGI-I, the Children's Yale-Brown Obsessive Compulsive Scale (CY-BOCS) (Scahill et al., 1997), and the Children's Global Assessment Scale (C-GAS) (Grant et al., 2014; Shaffer, Gould, Brasic, \& et al., 1983).

A pilot 12-week OLT evaluated six paediatric treatmentresistant OCD cases. Four of the patients showed a clinically significant response to treatment, as measured by the CY-BOCS and the CGI-I scale; all six opted to continue treatment. One of the patients who did not show clinically significant improvement during the 12-week trial did so thereafter (Grant, Lougee, Hirschtritt, \& Swedo, 2007).

\section{Adverse Events (Table S6)}

One case of pancreatitis was reported as an SAE in one RCT (Grant et al., 2014). In total, $6.6 \%$ of patients ( $n=7$; across the three included studies) showed transient elevations of liver function tests. This did not occur in any patients receiving placebo. Other AEs, e.g. increased salivation, showed roughly similar rates when comparing drug and placebo groups. Ghaleiha et al. reported an increase in appetite and body weight for subjects that received the combination of risperidone and riluzole (Ghaleiha, Mohammadi, et al., 2013).

\section{Discussion}

Drug development is a lengthy and costly process (Ciociola, Cohen, \& Kulkarni, 2014; Collier, 2009). To date, the vast majority of approved compounds have been developed directly by, or under the sponsorship of, pharmaceutical companies. Investigator initiated trials (IITs) are relatively rare. In child and adolescent psychiatry, traditionally, the interest of the pharmaceutical industry in developing novel compounds or seeking approval for compounds indicated in other disorders or age groups has been limited. This has led to a widespread use of off-label-prescriptions with a general lack of data from large clinical trials that have evaluated efficacy and tolerability/safety in representative patient samples. Accordingly, most trials included in this review are pilot studies and thus, methodological limitations apply and only restricted assumptions can be made. It needs to be noted that many of the trials included did not use outcome parameters, e.g. questionnaires, which explicitly reflect compulsivity and/or impulsivity. Due to the heterogeneity in trial designs and results, each compound is discussed separately in alphabetical order.

\section{D-Cycloserine}

Two RCTs did not show statistically significant differences between d-cycloserine and placebo when used as augmentation of behavioural therapy, although a statistically significantly faster treatment progress in patients receiving $d$ cycloserine was observed. The observed immediate effects on processes during CBT as well as the very good tolerability/safety profile may make d-cycloserine an interesting compound as a facilitating agent of CBT in further trials. Trials investigating the use of $\mathrm{d}$-cycloserine as either monotherapy or augmentation in OCD or other disorders to improve impulsivity/compulsivity do not appear reasonable at this point in time in view of the limited results available.

\section{Memantine}

Three OLTs in patients with ASD/PDD suggested statistically significant improvements in irritability, stereotypic behaviour, hyperactivity, attention, and memory. At the time of analysis, the first results of three large interconnected trials regarding memantine in ASD/PDD, sponsored by Forest Pharmaceuticals Inc., had only been presented as conference abstracts with mixed results having been reported. Thorough analyses and interpretations were yet to be published.

One pilot OLT with only $25 \%$ of patients $(n=4)$ completing the trial, was not enough to estimate effectiveness of memantine monotherapy in ADHD.

This review could not identify trials investigating memantine in paediatric OCD. But, as augmentation therapy in adult populations, memantine has been reported to improve OCD symptoms and lead to higher response and remission rates (Pittenger et al., 2011). Another review focusing on paediatric populations concluded that the reported putative benefits needed further evaluation and no general recommendations for a regular clinical use could be made at this point (Hosenbocus \& Chahal, 2013). Also, memantine's so far very beneficial safety and tolerability record was emphasized, which was mirrored by the findings of this systematic review. Most adverse events resembled those seen in adult dementia populations, i.e. headache, dizziness, and vomiting (European Medicines Agency, 2014). 


\section{Minocycline}

Minocycline showed promising results across symptom domains as an augmenting agent in the treatment of fragile $\mathrm{X}$ syndrome in all three trials included in this review. Yet, compulsivity as an outcome parameter was only described in one of these trials, with improvement reported for $20 \%$ of patients.

From the limited evidence available to date, no valid assumption can be derived regarding minocycline's efficacy in improving compulsivity/impulsivity. One trial in treatment-resistant OCD that included nine adult patients (therefore not included in this review) showed no statistically significant effect for an augmentation therapy with minocycline (Rodriguez et al., 2010). While comparable high rates of mild AEs (predominantly gastrointestinal distress) were reported for the only included RCT, investigating minocycline, rates were similar for treatment and placebo groups or even higher in the placebo group suggesting other causes than the compound minocycline.

\section{Modafinil}

Evidence for the use of modafinil in paediatric OCD or ASD/PDD is currently not available. In ADHD, however, three pooled paediatric trials reported statistically significant improvements in various domains of ADHD symptomatology as well as in global clinical status. As no specific outcome parameters for compulsivity were investigated, modafinil seems not to be a candidate for trials focusing on such traits/behavioural domains.

Decreased appetite was one of the most common AEs observed and is also a common AE in using psychostimulant medication, e.g. methylphenidate. This is an interesting finding since the precise mechanism of action for modafinil is still unclear, and modafinil and psychostimulants may share a common mechanism leading to a decrease in appetite (Davis et al., 2007; Goldfield, Lorello, \& Doucet, 2007).

\section{N-Acetylcysteine}

Evidence for $\mathrm{N}$-acetylcysteine in paediatric populations is very limited. Two RCTs suggest that $\mathrm{N}$-acetylcysteine is not effective in paediatric nail biting and trichotillomania. As an augmentation of risperidone therapy, N-acetylcysteine may be of benefit for paediatric ASD patients. This was the case in one RCT included in this review.

In adult OCD, more promising results and at the same time a lack of large controlled trials needed for further investigation and possible validation have been reported
(Lafleur et al., 2006; Grant, Odlaug, \& Kim, 2009; Dean et al., 2011; Pittenger et al., 2011; Berk et al., 2013). Taking into account the good tolerability/safety profile of $\mathrm{N}$-acetylcysteine, the compound may be a valuable candidate for an augmentation therapy in OCD as well as in ASD/PDD.

\section{Riluzole}

RCTs failed to confirm initial promising results from OLTs both in paediatric OCD and ASD/PDD. With very limited evidence available, no generally valid assumptions can be made (Grant, Song, \& Swedo, 2010; Pittenger et al., 2011).

In adults (not included in this review), several case reports, case series, and one pilot OLT have been published which all report augmentation with riluzole in treatmentresistant OCD (Coric et al., 2003; Coric et al., 2005; Mahgoub, Asemota, \& Alexopoulos, 2011; Pittenger, Kelmendi, Wasylink, Bloch, \& Coric, 2008). They unanimously reported favourable outcomes for all or most described patients.

Based on the reviewed literature, riluzole may be a valuable candidate for multicentre trials in adult rather than paediatric OCD. Although riluzole was generally well tolerated in the paediatric populations, one case of pancreatitis was reported for one of the trials included in the present review and another has been described in the literature (Pittenger et al., 2008). Currently, it remains unclear whether this may be a youth-specific problem. Nevertheless, future trials both in paediatric and adult populations need to be carefully set up in order to identify and minimize such severe adverse events.

\section{Limitations}

The trials included in this review involved a number of design and methodological limitations: On the study level, most trials were pilot studies. Nine out of the included 21 trials had an open-label design. Some were retrospective studies. Only three out of 21 trials investigated monotherapy of the respective compound. Hence, reported adverse event rates might be confounded by the augmented medication and/or interaction effects. Additionally, very few publications reported the methods used to assess adverse events. The AE rates presented should not be confused with data from large systematic tolerability/safety trials as they only result from information that was provided by the publications included in this review.

Although recommendations for reporting results from parallel group randomized trials such as the CONSORT statement (Moher, Schulz, \& Altman, 2001) have been in existence for longer than a decade, the collection and re- 
porting of treatment outcome data and adverse events varied widely. For instance, some publications did not mention $\mathrm{p}$-values for statistical analyses or calculate any effect sizes.

The impact of psychiatric comorbidity on treatmentoutcome was only evaluated in a few studies. This is an important consideration in disorders such as OCD, ADHD, and ASD, in which psychiatric co-morbidity is common (Jensen, Martin, \& Cantwell, 1997; Joshi et al., 2013; Martinez-Raga, Szerman, Knecht, \& de Alvaro, 2013). Many studies also failed to examine different disorder subtypes when evaluating treatment-response, which may be highly relevant for heterogeneous disorders such as OCD and ASD, particularly among child and adolescent populations (Grados \& Riddle, 2008; Starcevic \& Brakoulias, 2008).

On the review level, the six compounds investigated here may share their interference with glutamatergic activity in general yet their precise mechanisms of action, pharmacodynamics, and pharmacokinetics differ significantly. This severely restricts comparability of results across compounds. Finally, the trials reviewed here were conducted in many countries worldwide with different healthcare systems and, more importantly, cultural backgrounds which may be especially important in the perception and classification of psychiatric disorders.

\section{Conclusions}

The available data reviewed here support the suggestion that glutamatergic agents may be of potential value in the treatment of compulsivity/impulsivity in children and adolescents with OCD, ASD/PDD/FXS or ADHD. Yet, further formal controlled trials involving larger populations and longer treatment periods are needed to elucidate effectiveness, tolerability, and safety of glutamatergic compounds as treatment of compulsivity in children and adolescents. Based on the data reviewed, memantine and $\mathrm{N}$-acetylcysteine suggest the best risk-benefit profile for future trials. Riluzole should primarily be further investigated in adults. Clinical research of this nature is a key element of the TACTICS Consortium project funded by the European Union (FP7).

\section{Electronic supplementary material}

The electronic supplementary material is available with the online version of the article at https://doi.org/10.1024/ 1422-4917/a000546

ESM 1-ESM 6. Tables.

\section{References}

Abdel-Ahad, P., Kazour, F. (2013). Non-Antidepressant Pharmacological Treatment of Obsessive Compulsive Disorder: A Comprehensive Review. Curr Clin Pharmacol.

Aman, M.G., Burrow, W.H., Wolford, P.L. (1995). The Aberrant Behavior Checklist-Community: factor validity and effect of subject variables for adults in group homes. Am J Ment Retard, 100(3), 283-292.

American Psychiatric Association. (2013). Diagnostic and statistical manual of mental disorders: DSM-5 (A. American Psychiatric, Trans. Fifth ed.). Washington, DC American Psychiatric Assoc.

Berk, M., Malhi, G.S., Gray, L.J., Dean, O.M. (2013). The promise of $\mathrm{N}$-acetylcysteine in neuropsychiatry. Trends Pharmacol Sci, 34(3), 167-177. doi:10.1016/j.tips.2013.01.001.

Berry-Kravis, E., Krause, S.E., Block, S.S., Guter, S., Wuu, J., Leurgans, S., Hagerman, R. (2006). Effect of CX516, an AMPA-modulating compound, on cognition and behavior in fragile $X$ syndrome: a controlled trial. J Child Adolesc Psychopharmacol, 16(5), 525-540. doi: 10.1089/cap.2006.16.525.

Biederman, J., Faraone, S.V. (2005). Attention-deficit hyperactivity disorder. Lancet, 366(9481), 237-248. doi: 10.1016/S0140-6736 (05)66915-2.

Billstedt, E., Gillberg, I. C., Gillberg, C. (2007). Autism in adults: symptom patterns and early childhood predictors. Use of the DISCO in a community sample followed from childhood. J Child Psychol Psychiatry,48(11),1102-1110.doi:10.1111/j.1469-7610.2007.01774.x.

Bloch, M.H., Panza, K.E., Grant, J.E., Pittenger, C., Leckman, J.F. (2013). N-acetylcysteine in the treatment of pediatric trichotillomania: a randomized, double-blind, placebo-controlled add-on trial. J Am Acad Child Adolesc Psychiatry, 52(3), 231-240. doi: 10.1016/j.jaac.2012.12.020.

Brennan, B.P., Rauch, S.L., Jensen, J.E., Pope, H.G., Jr. (2013). A critical review of magnetic resonance spectroscopy studies of obsessive-compulsive disorder. Biol Psychiatry, 73(1), 24-31. doi: 10.1016/j.biopsych.2012.06.023.

Bristot Silvestrin, R., Bambini-Junior, V., Galland, F., Daniele Bobermim, L., Quincozes-Santos, A., Torres Abib, R., Gottfried, C. (2013). Animal model of autism induced by prenatal exposure to valproate: altered glutamate metabolism in the hippocampus. Brain Res, 1495, 52-60. doi:10.1016/j.brainres.2012.11.048.

Budimirovic, D.B., Kaufmann, W.E. (2011). What Can We Learn about Autism from Studying Fragile X Syndrome? Developmental Neuroscience, 33(5), 379-394. doi: 10.1159/000330213.

Carlsson, M.L. (1998). Hypothesis: is infantile autism a hypoglutamatergic disorder? Relevance of glutamate - serotonin interactions for pharmacotherapy. J Neural Transm, 105(4-5), 525-535.

Carlsson, M.L. (2000). On the role of cortical glutamate inobsessive-compulsive disorder and attention-deficit hyperactivity disorder, two phenomenologically antithetical conditions. Acta Psychiatr Scand, 102(6), 401-413. doi: 10.1034/j.1600-0447. 2000.102006401.x.

Carlsson, M. L. (2001). On the role of prefrontal cortex glutamate for the antithetical phenomenology of obsessive compulsive disorder and attention deficit hyperactivity disorder. Prog Neuropsychopharmacol Biol Psychiatry, 25(1), 5-26.

Carrey, N., MacMaster, F.P., Sparkes, S.J., Khan, S. C., Kusumakar, V. (2002). Glutamatergic changes with treatment in attention deficit hyperactivity disorder: a preliminary case series. J Child Adolesc Psychopharmacol, 12(4), 331-336. doi: 10.1089/ 104454602762599871.

Chakrabarty, K., Bhattacharyya, S., Christopher, R., Khanna, S. (2005). Glutamatergic dysfunction in OCD. Neuropsychopharmacology, 30(9), 1735-1740.

Chamberlain, S.R., Fineberg, N.A., Blackwell, A.D., Robbins, T.W., Sahakian, B.J. (2006). Motor inhibition and cognitive flexibility in 
obsessive-compulsive disorder and trichotillomania. Am J Psychiatry, 163(7), 1282-1284.

Chez, M. G., Burton, Q., Dowling, T., Chang, M., Khanna, P., Kramer, C. (2007). Memantine as adjunctive therapy in children diagnosed with autistic spectrum disorders: an observation of initial clinical response and maintenance tolerability. J Child Neurol, 22(5), 574-579.

Ciociola, A.A., Cohen, L. B., Kulkarni, P. (2014). How drugs are developed and approved by the FDA: current process and future directions. Am J Gastroenterol, 109(5), 620-623. doi: 10.1038/ ajg.2013.407.

Cohen, J. (1988). Statistical Power Analysis for the Behavioral Sciences: Lawrence Erlbaum Associates.

Collier, R. (2009). Drug development cost estimates hard to swallow. CMAJ, 180(3), 279-280. doi: 10.1503/cmaj.082040.

Conners, C.K., Sitarenios, G., Parker, J. D., Epstein, J. N. (1998). The revised Conners' Parent Rating Scale (CPRS-R): factor structure, reliability, and criterion validity. J Abnorm Child Psychol, 26(4), 257-268.

Constantino, J.N., Davis, S.A., Todd, R.D., Schindler, M.K., Gross, M. M., Brophy, S. L., Reich, W. (2003). Validation of a brief quantitative measure of autistic traits: comparison of the social responsiveness scale with the autism diagnostic interview-revised. J Autism Dev Disord, 33(4), 427-433.

Coric, V., Milanovic, S., Wasylink, S., Patel, P., Malison, R., Krystal, J.H. (2003). Beneficial effects of the antiglutamatergic agent riluzole in a patient diagnosed with obsessive-compulsive disorder and major depressive disorder. Psychopharmacology (Berl), 167(2), 219-220.

Coric, V., Taskiran, S., Pittenger, C., Wasylink, S., Mathalon, D.h., Valentine, G., Krystal, J.H. (2005). Riluzole augmentation in treatment-resistant obsessive-compulsive disorder: an openlabel trial. Biol Psychiatry, 58(5), 424-428.

Davis, C., Levitan, R.D., Kaplan, A.S., Carter, J., Reid, C., Curtis, C. Kennedy, J.L. (2007). Dopamine transporter gene (DAT1) associated with appetite suppression to methylphenidate in a casecontrol study of binge eating disorder. Neuropsychopharmacology, 32(10), 2199-2206. doi:10.1038/sj.npp.1301348.

Dean, O., Giorlando, F., Berk, M. (2011). N-acetylcysteine in psychiatry: current therapeutic evidence and potential mechanisms of action. J Psychiatry Neurosci, 36(2), 78-86. doi: 10.1503/jpn.100057

Dean, O.M., Data-Franco, J., Giorlando, F., Berk, M. (2012). Minocycline: therapeutic potential in psychiatry. CNS Drugs, 26(5), 391401. doi: 10.2165/11632000-000000000-00000.

Douglass, H. M., Moffitt, T.E., Dar, R., McGee, R., Silva, P. (1995). Obsessive-compulsive disorder in a birth cohort of 18-year-olds: prevalence and predictors. J Am Acad Child Adolesc Psychiatry, 34(11), 1424-1431. doi: 10.1097/00004583-199511000-00008.

DuPaul, G.J., Power, T.J., Anastopoulos, A. D., Reid, R. (1998). ADHD rating scale-IV : checklists, norms, and clinical interpretation. New York: Guilford Press.

Durston, S., van Belle, J., de Zeeuw, P. (2011). Differentiating frontostriatal and fronto-cerebellar circuits in attention-deficit/hyperactivity disorder. Biol Psychiatry, 69(12), 1178-1184. doi: 10.1016/j.biopsych.2010.07.037.

Erickson, C.A., Posey, D.J., Stigler, K.A., Mullett, J., Katschke, A. R., McDougle, C.J. (2007). A retrospective study of memantine in children and adolescents with pervasive developmental disorders. Psychopharmacology (Berl), 191(1), 141-147.

Erickson, C.A., Weng, N., Weiler, I.J., Greenough, W.T., Stigler, K.A., Wink, L.K., McDougle, C.J. (2011). Open-label riluzole in fragile X syndrome. Brain Res, 1380, 264-270. doi: 10.1016/j.brainres. 2010.10.108.

Erickson, C.A., Wink, L.K., Ray, B., Early, M.C., Stiegelmeyer, E., Mathieu-Frasier, L., ... McDougle, C.J. (2013). Impact of acamprosate on behavior and brain-derived neurotrophic factor: an open- label study in youth with fragile $X$ syndrome. Psychopharmacology (Berl), 228(1), 75-84. doi: 10.1007/s00213-013-3022-z.

European Medicines Agency. (2014). Product Information: Axura $10 \mathrm{mg}$ film-coated tablets. from http://www.google.de/url?sa=t $\& r c t=j \& q=\& e s r c=s \&$ source $=$ web \&cd $=1 \& v e d=0$ CCEQFjAA\&url =http $\% 3 \mathrm{~A} \% 2 \mathrm{~F} \% 2$ Fwww.ema.europa.eu $\% 2$ Fdocs $\% 2$ Fen GB\%2Fdocument_library\%2FEPAR_-_Product_Information\% 2Fhuman\%2F000378\%2FWC500029678.pdf\&ei=5ehmVdKKYGOU_PVgMAL\&usg=AFQjCNFogx7BKvr_fLns8dnwpmOvQDS oPg\&bvm =bv.93990622,d.d24\&cad =rja.

European Medicines Agency. (2015a). EPAR Product Information: RILUTEK 50 mg film-coated tablets.

European Medicines Agency. (2015b). EPAR summary for the public: Memantine Merz (memantine hydrochloride). from http:// www.ema.europa.eu/ema/index.jsp?curl=pages/medicines/ human/medicines/002711/human_med_001599.jsp\&mid= WC0b01ac058001d124.

Farrell, L.J., Waters, A.M., Boschen, M.J., Hattingh, L., McConnell, H., Milliner, E.L., Storch, E.A. (2013). Difficult-to-treat pediatric obsessive-compulsive disorder: feasibility and preliminary results of a randomized pilot trial of D-cycloserine-augmented behavior therapy. Depress Anxiety, 30(8), 723-731. doi:10.1002/ da.22132.

Findling, R.L., McNamara, N.K., Stansbrey, R.J., Maxhimer, R., Periclou, A., Mann, A., Graham, S. M. (2007). A pilot evaluation of the safety, tolerability, pharmacokinetics, and effectiveness of memantine in pediatric patients with attention-deficit/hyperactivity disorder combined type. J Child Adolesc Psychopharmacol, 17(1), 19-33.

Fineberg, N. A., Potenza, M. N., Chamberlain, S. R., Berlin, H. A., Menzies, L., Bechara, A., Hollander, E. (2010). Probing compulsive and impulsive behaviors, from animal models to endophenotypes: a narrative review. Neuropsychopharmacology, 35(3), 591-604.

Flament, M.F., Whitaker, A., Rapoport, J.L., Davies, M., Berg, C.Z., Kalikow, K., Shaffer, D. (1988). Obsessive Compulsive Disorder in Adolescence: An Epidemiological Study. Journal of the American Academy of Child \& Adolescent Psychiatry, 27(6), 764-771. doi: http://dx.doi.org/10.1097/00004583-198811000-00018.

Food and Drug Administration, U. (2006). Package Insert: Acetadote ${ }^{\circledR}$ (acetylcysteine) Injection. from http://www.accessdata. fda.gov/drugsatfda_docs/label/2006/021539s004lbl.pdf.

Food and Drug Administration, U. (2009). DESCRIPTION: RILUTEK ${ }^{\circledR}$ (riluzole). from http://www.ema.europa.eu/ema/index.jsp?curl= pages/medicines/human/medicines/000109/human_ med_001039.jsp\&mid=WC0b01ac058001d124.

Food and Drug Administration, U. (2010). Mecial Review NDA 22525, Namenda ${ }^{\circledR} X R$, Forest Laboratories. from http://www.accessdata. fda.gov/drugsatfda_docs/label/2010/022525s000lbl.pdf.

Food and Drug Administration, U. (2015). PROVIGIL ${ }^{\circledR}$ MEDICATION GUIDE (modafinil) from http://www.fda.gov/downloads/Drugs/ DrugSafety/UCM231722.pdf.

Gantois, I., Pop, A.S., de Esch, C.E., Buijsen, R.A., Pooters, T., Gomez-Mancilla, B., Willemsen, R. (2013). Chronic administration of AFQ056/Mavoglurant restores social behaviour in Fmr1 knockout mice. Behav Brain Res, 239, 72-79. doi: 10.1016/j. bbr.2012.10.059.

Garber, K. B., Visootsak, J., Warren, S.T. (2008). Fragile X syndrome. Eur J Hum Genet, 16(6), 666-672. doi: 10.1038/ejhg.2008.61.

Gerrard, P., Malcolm, R. (2007). Mechanisms of modafinil: A review of current research. Neuropsychiatr Dis Treat, 3(3), 349-364.

Ghaleiha, A., Asadabadi, M., Mohammadi, M. R., Shahei, M., Tabrizi, M., Hajiaghaee, R., Akhondzadeh, S. (2013). Memantine as adjunctive treatment to risperidone in children with autistic disorder: a randomized, double-blind, placebo-controlled trial. Int J Neuropsychopharmacol, 16(4), 783-789. doi: 10.1017/s146114 5712000880. 
Ghaleiha, A., Mohammadi, E., Mohammadi, M.R., Farokhnia, M., Modabbernia, A., Yekehtaz, H., Akhondzadeh, S. (2013). Riluzole as an adjunctive therapy to risperidone for the treatment of irritability in children with autistic disorder: a double-blind, placebo-controlled, randomized trial. Paediatr Drugs, 15(6), 505-514. doi: 10.1007/s40272-013-0036-2.

Ghanizadeh, A., Derakhshan, N., Berk, M. (2013). N-acetylcysteine versus placebo for treating nail biting, a double blind randomized placebo controlled clinical trial. Antiinflamm Antiallergy Agents Med Chem, 12(3), 223-228.

Ghanizadeh, A., Moghimi-Sarani, E. (2013). A randomized double blind placebo controlled clinical trial of N-Acetylcysteine added to risperidone for treating autistic disorders. BMC Psychiatry, 13, 196. doi: 10.1186/1471-244x-13-196.

Goldfield, G.S., Lorello, C., Doucet, E. (2007). Methylphenidate reduces energy intake and dietary fat intake in adults: a mechanism of reduced reinforcing value of food? Am J Clin Nutr, 86(2), 308-315.

Grados, M., Riddle, M.A. (2008). Do all obsessive-compulsive disorder subtypes respond to medication? Int Rev Psychiatry, 20(2), 189-193. doi: 10.1080/09540260801889153.

Grant, J. E., Odlaug, B.L., Kim, S.W. (2009). N-acetylcysteine, a glutamate modulator, in the treatment of trichotillomania: a double-blind, placebo-controlled study. Arch Gen Psychiatry, 66(7), 756-763. doi:10.1001/archgenpsychiatry.2009.60.

Grant, P., Lougee, L., Hirschtritt, M., Swedo, S.E. (2007). An openlabel trial of riluzole, a glutamate antagonist, in children with treatment-resistant obsessive-compulsive disorder. J Child Adolesc Psychopharmacol, 17(6), 761-767.

Grant, P., Song, J.Y., Swedo, S.E. (2010). Review of the use of the glutamate antagonist riluzole in psychiatric disorders and a description of recent use in childhood obsessive-compulsive disorder. J Child Adolesc Psychopharmacol, 20(4), 309-315. doi: 10.1089/cap.2010.0009

Grant, P.J., Joseph, L.A., Farmer, C.A., Luckenbaugh, D.A., Lougee, L.C., Zarate, C.A., Jr., Swedo, S.E. (2014). 12-Week, PlaceboControlled Trial of Add-on Riluzole in the Treatment of Childhood-Onset Obsessive-Compulsive Disorder. Neuropsychopharmacology, 39(6), 1453-1459.

Guy, W. (1976). ECDEU assessment manual for psychopharmacology: US Department of Health, Education, and Welfare, Public Health Service, Alcohol, Drug Abuse, and Mental Health Administration, National Institute of Mental Health, Psychopharmacology Research Branch, Division of Extramural Research Programs.

Hagerman, R., Lauterborn, J., Au, J., Berry-Kravis, E. (2012). Fragile $X$ syndrome and targeted treatment trials. Results Probl Cell Differ, 54, 297-335. doi: 10.1007/978-3-642-21649-7_17.

Hall, S.S., Lightbody, A. A., Reiss, A. L. (2008). Compulsive, self-injurious, and autistic behavior in children and adolescents with fragile X syndrome. Am J Ment Retard, 113(1), 44-53. doi: 10.1352/0895-8017(2008)113[44:csaabi]2.0.co;2.

Hardan, A. (2014). Efficacy and Safety of Memantine in a Global, Double-Blind, Placebo-Controlled, Randomized Withdrawal Study in Children With Autism Spectrum Disorder: Poster Session: The 167th annual meeting of the American Psychiatric Association. $P \& T^{\oplus}$ • June $2014 \cdot 39(450)$.

Hendren, R. (2014). Memantine in Children with Autism: Results From a Two-Part, Open-Label/Double-Blind Randomized, Placebo-Controlled Trial and an Open-Label Extension: Poster Session 6, The 167th annual meeting of the American Psychiatric Association.

Hersh, J.H., Saul, R.A. (2011). Health supervision for children with fragile X syndrome. Pediatrics, 127(5), 994-1006. doi: 10.1542/ peds.2010-3500.

Heyman, I., Fombonne, E., Simmons, H., Ford, T., Meltzer, H., Goodman, R. (2001). Prevalence of obsessive-compulsive disorder in the British nationwide survey of child mental health. Br J Psychiatry, 179, 324-329.

Hollander, E., Kwon, J.H., Stein, D.J., Broatch, J., Rowland, C.T., Himelein, C.A. (1996). Obsessive-compulsive and spectrum disorders: overview and quality of life issues. J Clin Psychiatry, 57 Suppl 8, 3-6.

Horder, J., Lavender, T., Mendez, M.A., O'Gorman, R., Daly, E., Craig, M.C., Murphy, D.G. (2013). Reduced subcortical glutamate/glutamine in adults with autism spectrum disorders: a [(1)H]MRS study. Transl Psychiatry, 3(7), e279. doi:10.1038/tp.2013.53.

Hosenbocus, S., Chahal, R. (2013). Memantine: a review of possible uses in child and adolescent psychiatry. J Can Acad Child Adolesc Psychiatry, 22(2), 166-171.

Jacquemont, S., Curie, A., des Portes, V., Torrioli, M. G., Berry-Kravis, E., Hagerman, R.J., Gomez-Mancilla, B. (2011). Epigenetic modification of the FMR1 gene in fragile $X$ syndrome is associated with differential response to the MGluR5 antagonist AFQ056. Sc Transl Med, 3(64), 64ra61. doi:10.1126/scitranslmed.3001708.

Javitt, D.C. (2004). Glutamate as a therapeutic target in psychiatric disorders. Mol Psychiatry, 9(11), 984-997, 979. doi: 10.1038/sj. mp.4001551.

Jensen, P.S., Martin, D., Cantwell, D.P. (1997). Comorbidity in ADHD: implications for research, practice, and DSM-V.J Am Acad Child Adolesc Psychiatry, 36(8), 1065-1079. doi: 10.1097/00004583199708000-00014.

Johnson, J.W., Kotermanski, S.E. (2006). Mechanism of action of memantine. Curr Opin Pharmacol, 6(1), 61-67. doi: 10.1016/j. coph.2005.09.007.

Joshi, G., Wozniak, J., Petty, C., Martelon, M.K., Fried, R., Bolfek, A., Biederman, J. (2013). Psychiatric comorbidity and functioning in a clinically referred population of adults with autism spectrum disorders: a comparative study. J Autism Dev Disord, 43(6), 1314-1325. doi: 10.1007/s10803-012-1679-5.

Kamath, P., Reddy, Y.C., Kandavel, T. (2007). Suicidal behavior in obsessive-compulsive disorder. J Clin Psychiatry, 68(11), 1741-1750.

Kessler, R.C., Adler, L.A., Barkley, R., Biederman, J., Conners, C.K., Faraone, S.V., Zaslavsky, A. M. (2005). Patterns and predictors of attention-deficit/hyperactivity disorder persistence into adulthood: results from the national comorbidity survey replication. Biol Psychiatry, 57(11), 1442-1451. doi: 10.1016/j.biopsych. 2005.04.001.

Klassen, A. F., Miller, A., Fine, S. (2004). Health-related quality of life in children and adolescents who have a diagnosis of attentiondeficit/hyperactivity disorder. Pediatrics, 114(5), e541-547. doi: 10.1542/peds.2004-0844.

Koob, G.F., Le Moal, M. (1997). Drug abuse: hedonic homeostatic dysregulation. Science, 278(5335), 52-58.

Kotecha, S. A., Oak, J. N., Jackson, M. F., Perez, Y., Orser, B. A., Van Tol, H.H., MacDonald, J.F. (2002). A D2 class dopamine receptor transactivates a receptor tyrosine kinase to inhibit NMDA receptor transmission. Neuron, 35(6), 1111-1122.

Kretschmer, B.D., Kratzer, U., Schmidt, W.J. (1998). Riluzole, a glutamate release inhibitor, and motor behavior. Naunyn Schmiedebergs Arch Pharmacol, 358(2), 181-190.

Lafleur, D. L., Pittenger, C., Kelmendi, B., Gardner, T., Wasylink, S., Malison, R.T., Coric, V. (2006). N-acetylcysteine augmentation in serotonin reuptake inhibitor refractory obsessive-compulsive disorder. Psychopharmacology (Berl), 184(2), 254-256. doi: 10.1007/s00213-005-0246-6.

Lambert, M.P., Neuhaus, F.C. (1972). Mechanism of D-cycloserine action: alanine racemase from Escherichia coli W. J Bacteriol, $110(3), 978-987$

Laupacis, A., Sackett, D. L., Roberts, R.S. (1988). An assessment of clinically useful measures of the consequences of treatment. N Engl J Med, 318(26), 1728-1733. doi:10.1056/nejm1988063031 82605. 
Leigh, M.J., Nguyen, D.V., Mu, Y., Winarni, T.I., Schneider, A., Chechi, T., Hagerman, R.J. (2013). A randomized double-blind, placebocontrolled trial of minocycline in children and adolescents with fragile $x$ syndrome. J Dev Behav Pediatr, 34(3), 147-155. doi: 10.1097/DBP.0b013e318287cd17.

Lewin, A.B., Storch, E.A., Geffken, G.R., Goodman, W. K., Murphy, T.K. (2006). A neuropsychiatric review of pediatric obsessivecompulsive disorder: etiology and efficacious treatments. Neuropsychiatr Dis Treat, 2(1), 21-31.

Ludolph, A. G., Udvardi, P.T., Schaz, U., Henes, C., Adolph, O., Weigt, H.U., Fohr, K.J. (2010). Atomoxetine acts as an NMDA receptor blocker in clinically relevant concentrations. Br J Pharmacol, 160(2), 283-291. doi: 10.1111/j.1476-5381.2010.00707.x.

Mahgoub, N., Asemota, B., Alexopoulos, G.S. (2011). The effect of riluzole augmentation in a patient with treatment-resistant obsessive-compulsive disorder, taking two other glutaminergic agents. J Neuropsychiatry Clin Neurosci, 23(2), E24-25. doi: 10.1176/appi.neuropsych.23.2.E24.

Mancuso, E., Faro, A., Joshi, G., Geller, D.A. (2010). Treatment of pediatric obsessive-compulsive disorder: a review. J Child Adolesc Psychopharmacol, 20(4), 299-308.

Martinez-Raga, J., Szerman, N., Knecht, C., de Alvaro, R. (2013). Attention deficit hyperactivity disorder and dual disorders. Educational needs for an underdiagnosed condition. Int J Adolesc Med Health, 25(3), 231-243. doi:10.1515/ijamh-2013-0057.

Marzullo, L. (2005). An update of $\mathrm{N}$-acetylcysteine treatment for acute acetaminophen toxicity in children. Curr Opin Pediatr, 17(2), 239-245.

McDougle, C.J., Erickson, C.A., Stigler, K.A., Posey, D.J. (2005). Neurochemistry in the pathophysiology of autism. J Clin Psychiatry, 66 Suppl 10, 9-18.

McLennan, Y., Polussa, J., Tassone, F., Hagerman, R. (2011). Fragile x syndrome. Curr Genomics, 12(3), 216-224. doi: 10.2174/ 138920211795677886

McQuay, H.J., Moore, R. A. (1997). Using numerical results from systematic reviews in clinical practice. Ann Intern Med, 126(9), 712-720.

Melmed, R. (2014). Safety and Tolerability of Memantine in Children With Autism Spectrum Disorder (ASD): Results From an Open-Label, International Trial. Poster Session, The 167th annual meeting of the American Psychiatric Association. 2014.

Moher, D., Liberati, A., Tetzlaff, J., Altman, D.G., Group, P. (2009). Preferred reporting items for systematic reviews and metaanalyses: the PRISMA statement. J Clin Epidemiol, 62(10), 1006-1012. doi: 10.1016/j.jclinepi.2009.06.005.

Moher, D., Schulz, K. F., Altman, D. G. (2001). The CONSORT statement: revised recommendations for improving the quality of reports of parallel group randomized trials. BMC Med Res Methodol, 1, 2.

Monaghan, D.T., Yao, D., Cotman, C.W. (1985). L-[3H] Glutamate binds to kainate-, NMDA- and AMPA-sensitive binding sites: an autoradiographic analysis. Brain Res, 340(2), 378-383.

Naaijen, J., Lythgoe, D.J., Amiri, H., Buitelaar, J.K., Glennon, J.C. (2015). Fronto-striatal glutamatergic compounds in compulsive and impulsive syndromes: A review of magnetic resonance spectroscopy studies. Neurosci Biobehav Rev. doi: 10.1016/j. neubiorev.2015.02.009.

Nestadt, G., Di, C.Z., Riddle, M.A., Grados, M.A., Greenberg, B.D., Fyer, A.J., Roche, K.B. (2009). Obsessive-compulsive disorder: subclassification based on co-morbidity. Psychol Med, 39(9), 1491-1501. doi: 10.1017/s0033291708004753.

Owley, T., Salt, J., Guter, S., Grieve, A., Walton, L., Ayuyao, N., Leventhal, BL., Cook, EH. (2006). A prospective, open-label trial of memantine in the treatment of cognitive, behavioral, and memory dysfunction in pervasive developmental disorders. $J$ Child Adolesc Psychopharmacol, 16(5), 517-24.
Parellada, M., Penzol, M.J., Pina, L., Moreno, C., Gonzalez-Vioque, E., Zalsman, G., Arango, C. (2014). The neurobiology of autism spectrum disorders. Eur Psychiatry, 29(1), 11-19. doi:10.1016/j. eurpsy.2013.02.005.

Paribello, C., Tao, L., Folino, A., Berry-Kravis, E., Tranfaglia, M., Ethell, I.M., Ethell, D.W. (2010). Open-label add-on treatment trial of minocycline in fragile $X$ syndrome. BMC Neurol, 10, 91. doi: 10.1186/1471-2377-10-91.

Parsons, C.G., Stoffler, A., Danysz, W. (2007). Memantine: a NMDA receptor antagonist that improves memory by restoration of homeostasis in the glutamatergic system - too little activation is bad, too much is even worse. Neuropharmacology, 53(6), 699723. doi: 10.1016/j.neuropharm.2007.07.013

Pittenger, C., Bloch, M.H., Williams, K. (2011). Glutamate abnormalities in obsessive compulsive disorder: neurobiology, pathophysiology, and treatment. Pharmacol Ther, 132(3), 314-332. doi: 10.1016/j.pharmthera.2011.09.006.

Pittenger, C., Kelmendi, B., Wasylink, S., Bloch, M. H., Coric, V. (2008). Riluzole augmentation in treatment-refractory obsessive-compulsive disorder: a series of 13 cases, with long-term follow-up. J Clin Psychopharmacol, 28(3), 363-367. doi:10.1097/JCP.0b013e 3181727548.

Polanczyk, G., Rohde, L.A. (2007). Epidemiology of attention-deficit/hyperactivity disorder across the lifespan. Curr Opin Psychiatry, 20(4), 386-392. doi: 10.1097/YC0.0b013e3281568d7a.

Polanczyk, G.V., Willcutt, E.G., Salum, G.A., Kieling, C., Rohde, L.A. (2014). ADHD prevalence estimates across three decades: an updated systematic review and meta-regression analysis. Int $J$ Epidemiol, 43(2), 434-442. doi: 10.1093/ije/dyt261.

Pop, A.S., Levenga, J., de Esch, C.E., Buijsen, R.A., Nieuwenhuizen, I. M., Li, T., Willemsen, R. (2014). Rescue of dendritic spine phenotype in Fmr1 KO mice with the mGluR5 antagonist AFQ056/Mavoglurant. Psychopharmacology (Berl), 231(6), 1227-1235. doi: 10.1007/s00213-012-2947-y.

Posey, D.J., Kem, D.L., Swiezy, N.B., Sweeten, T.L., Wiegand, R.E., McDougle, C.J. (2004). A pilot study of D-cycloserine in subjects with autistic disorder. Am J Psychiatry, 161(11), 2115-2117. doi: 10.1176/appi.ajp.161.11.2115.

Prosser, G. A., de Carvalho, L.P. (2013). Kinetic mechanism and inhibition of Mycobacterium tuberculosis D-alanine:D-alanine ligase by the antibiotic D-cycloserine. Febs j, 280(4), 1150-1166. doi: $10.1111 /$ febs.12108.

Ramachandran, G., Swaminathan, S. (2015). Safety and Tolerability Profile of Second-Line Anti-Tuberculosis Medications. Drug Safety, 38(3), 253-269. doi: 10.1007/s40264-015-0267-y.

Rodriguez, C.I., Bender, J., Jr., Marcus, S. M., Snape, M., Rynn, M., Simpson, H.B. (2010). Minocycline augmentation of pharmacotherapy in obsessive-compulsive disorder: an open-label trial. $J$ Clin Psychiatry, 71 (9), 1247-1249. doi:10.4088/JCP.09105805blu.

Rosenberg, D.R., Hanna, G. L. (2000). Genetic and imaging strategies in obsessive-compulsive disorder: potential implications for treatment development. Biol Psychiatry, 48(12), 1210-1222.

Rosenberg, D. R., MacMaster, F.P., Keshavan, M.S., Fitzgerald, K. D., Stewart, C.M., Moore, G.J. (2000). Decrease in caudate glutamatergic concentrations in pediatric obsessive-compulsive disorder patients taking paroxetine. J Am Acad Child Adolesc Psychiatry, 39(9), 1096-1103.

Rubia, K., Cubillo, A., Smith, A. B., Woolley, J., Heyman, I., Brammer, M.J. (2010). Disorder-specific dysfunction in right inferior prefrontal cortex during two inhibition tasks in boys with attentiondeficit hyperactivity disorder compared to boys with obsessivecompulsive disorder. Hum Brain Mapp, 31(2), 287-299. doi: 10.1002/hbm.20864.

Rubia, K., Cubillo, A., Woolley, J., Brammer, M.J., Smith, A. (2011). Disorder-specific dysfunctions in patients with attention-deficit/hyperactivity disorder compared to patients with obsessive- 
compulsive disorder during interference inhibition and attention allocation. Hum Brain Mapp, 32(4), 601-611. doi: 10.1002/ hbm.21048.

Scahill, L., Riddle, M.A., McSwiggin-Hardin, M., Ort, S.I., King, R.A., Goodman, W. K., Leckman, J. F. (1997). Children's Yale-Brown Obsessive Compulsive Scale: reliability and validity. J Am Acad Child Adolesc Psychiatry, 36(6), 844-852.

Shaffer, D., Gould, M.S., Brasic, J., et al. (1983). A childrens global assessment scale (cgas). Arch Gen Psychiatry, 40(11), 1228-1231.

Silverman, J. L., Tolu, S. S., Barkan, C. L., Crawley, J. N. (2010). Repetitive self-grooming behavior in the BTBR mouse model of autism is blocked by the MGluR5 antagonist MPEP. Neuropsychopharmacology, 35(4), 976-989. doi: 10.1038/npp. 2009.201.

Sourial, M., Cheng, C., Doering, L.C. (2013). Progress toward therapeutic potential for AFQ056 in Fragile X syndrome. Journal of Experimental Pharmacology, 5, 45-54. doi: 10.2147/JEP. S27044.

Starcevic, V., Brakoulias, V. (2008). Symptom subtypes of obsessivecompulsive disorder: are they relevant for treatment? Aust N Z J Psychiatry, 42(8), 651-661. doi: 10.1080/00048670802203442.

Storch, E.A., Murphy, T.K., Goodman, W.K., Geffken, G.R., Lewin, A. B., Henin, A., Geller, D.A. (2010). A preliminary study of D-cycloserine augmentation of cognitive-behavioral therapy in pediatric obsessive-compulsive disorder. Biol Psychiatry, 68(11), 1073-1076. doi: 10.1016/j.biopsych.2010.07.015.

Thalheimer, W., Cook, S. (2002). How to calculate effect sizes from published research: A simplified methodology. Work-Learning Research.

Ting, J.T., Feng, G. (2008). Glutamatergic Synaptic Dysfunction and Obsessive-Compulsive Disorder. Curr Chem Genomics, 2, 62-75. doi: 10.2174/1875397300802010062.

Turic, D., Langley, K., Mills, S., Stephens, M., Lawson, D., Govan, C., Thapar, A. (2004). Follow-up of genetic linkage findings on chromosome 16p13: evidence of association of N-methyl-D aspartate glutamate receptor $2 \mathrm{~A}$ gene polymorphism with ADHD. Mol Psychiatry, 9(2), 169-173. doi:10.1038/sj.mp.4001387.

U.S. National Library of Medicine. (2014). HUMAN PRESCRIPTION DRUG LABEL: ACETYLCYSTEINE. from http://dailymed.nlm.nih. gov/dailymed/druglnfo.cfm?setid=f56b4087-db48-4fd7-84ec9c927962b805.

Utari, A., Chonchaiya, W., Rivera, S.M., Schneider, A., Hagerman, R.J., Faradz, S.M., Nguyen, D.V. (2010). Side effects of minocycline treatment in patients with fragile $X$ syndrome and exploration of outcome measures. Am J Intellect Dev Disabil, 115(5), 433-443. doi: 10.1352/1944-7558-115.5.433.

Virring, A., Lambek, R., Jennum, P.J., Møller, L.R., Thomsen, P.H. (2017). Sleep Problems and Daily Functioning in Children With ADHD: An Investigation of the Role of Impairment, ADHD Presentations, and Psychiatric Comorbidity. J Atten Disord, 21(9), 731740. doi: 10.1177/1087054714542001.

Vrij, de, F.M., Levenga, J., van der Linde, H.C., Koekkoek, S. K., De Zeeuw, C.I., Nelson, D. L., Willemsen, R. (2008). Rescue of behavioral phenotype and neuronal protrusion morphology in Fmr1 KO mice. Neurobiol Dis, 31(1), 127-132. doi: 10.1016/j. nBd. 2008.04.002.

Wigal, S. B., Biederman, J., Swanson, J. M., Yang, R., Greenhill, L. L. (2006). Efficacy and safety of modafinil film-coated tablets in children and adolescents with or without prior stimulant treatment for attention-deficit/hyperactivity disorder: pooled analysis of 3 randomized, double-blind, placebo-controlled studies. Prim Care Companion J Clin Psychiatry, 8(6), 352-360.

Wolff, J.J., Hazlett, H.C., Lightbody, A. A., Reiss, A. L., Piven, J. (2013). Repetitive and self-injurious behaviors: associations with caudate volume in autism and fragile $X$ syndrome. J Neurodev Disord, 5(1), 12. doi: 10.1186/1866-1955-5-12.
Zeeuw, de, P., Mandl, R.C., Hulshoff Pol, H.E., van Engeland, H., Durston, S. (2012). Decreased frontostriatal microstructural organization in attention deficit/hyperactivity disorder. Hum Brain Mapp, 33(8), 1941-1951. doi:10.1002/hbm.21335.

Funding source: The research leading to these results has received funding from the European Community's Seventh Framework Programme (FP7/2007-2013) under grant agreement $n^{\circ} 278948$ (TACTICS project). This manuscript reflects only the authors' views and the European Union is not liable for any use that may be made of the information contained therein.

Financial Disclosure: The authors have no financial interests in this manuscript.

\section{Members of the TACTICS Consortium:}

Radboud University Medical Centre and Karakter Child and Adolescent Psychiatry University Centre, Nijmegen, The Netherlands

Saskia de Ruiter, Sophie Akkermans, Maarten Mennes, Marcel Zwiers, Sharhzad Ilbegi, Leonie Hennissen, Jill Naaijen, Ilse van de Vondervoort, Katarzyna Kapusta, Natalia Bielczyk, Houshang Amiri, Charlotte Oomen, Martha Havenith, Barbara Franke, Geert Poelmans, Janita Bralten, Tom Heskes, and Elena Sokolova

Institute of Psychiatry, Psychology and Neuroscience, King's College London, London, United Kingdom

David Lythgoe, Muriel Bruchhage, and lulia Dud

Department of Child and Adolescent Psychiatry and Psychotherapy, Central Institute of Mental Health, Medical Faculty Mannheim, University of Heidelberg, Mannheim, Germany Daniel Brandeis, Sarah Hohmann, Regina Boecker, Isabella Wolf, Ruth Berg, and Sabina Millenet

School of Psychological Sciences and Sagol School of Neuroscience, Tel-Aviv University, Tel Aviv, Israel Daphna Joel

Department of Anatomy and Neuroscience, University College Cork, Cork, Ireland

John F. Cryan

Harvard Medical School, Psychiatric and Neurodevelopmental Genetics Unit, Center for Human Genetic Research, Massachusetts General Hospital, Boston, MA, United States of America Tracey Petryshen, David Pauls, and Mai Saito

\section{University Medical Center Utrecht, the Netherlands}

Erwin Blezer, Kajo van der Marel, Pim Pullens, Wouter Mol, Annette van der Toorn, Wim Otte, Caroline van Heijningen, Vincent Mensen, Bob Oranje, and Rene Mandl

\section{genOway, Lyon, France}

Angelique Heckmann

\section{Department of Chemical Engineering and Biotechnology, University of Cambridge, Cambridge, United Kingdom} Sabine Bahn

\section{Concentris Research Management GmbH, Fürstenfeldbruck, Germany}

Ameli Schwalber

\section{H. Lundbeck A/S, Copenhagen, Denmark}

Philippe Auby 
Submitted: 26.04.2017

Accepted after revision: 30.07 .2017

Published online: 18.09.2017

Conflicts of interest:

KM has served as sub-investigator in clinical trials conducted by Shire and Sunovion, plus in EU FP7 programme funded projects. $\mathrm{AH}$ has served as sub-investigator in clinical trials conducted by Janssen-Cilag, Otsuka, Shire, Sunovion, plus in EU FP7 programme funded projects. He has received conference travel support and compensation for serving as consultant or speaker by E. Lilly and Shire.

NS reports no potential conflicts of interest. JCG reports no potential conflicts of interest. RMD reports no potential conflicts of interest. DM reports no potential conflicts of interest. SD reports no potential conflicts of interest. SCRW reports no potential conflicts of interest. JB has been in the past three years a consultant to / member of advisory board of / and/or speaker for Janssen Cilag BV, Eli Lilly, Lundbeck, and Servier. He is not an employee of any of these companies, and not a stock shareholder of any of these companies. He receives no other financial or material support, including expert testimony, patents, royalties. TB served in an advisory or consultancy role for Actelion, Hexal Pharma, Lilly, Medice, Novartis, Oxford outcomes, PCM scientific, Shire and
Viforpharma. He received conference support or speaker's fee by Janssen McNeil, Lilly, Medice, Novartis and Shire. He is/has been involved in clinical trials conducted by Shire \& Viforpharma. The present work is unrelated to the abovementioned grants and relationships. RWD has received compensation for serving as consultant or speaker, or he or the institution he works for have received research support or royalties from the organizations or companies indicated: EU (FP7 Programme), US National Institute of Mental Health (NIMH), German Federal Ministry of Health/ Regulatory Agency (BMG/BfArM), German Federal Ministry of Education and Research (BMBF), German Research Foundation (DFG), Volkswagen Foundation; Boehringer Ingelheim, Ferring, Janssen-Cilag, E. Lilly, Otsuka, Shire, Sunovion/Takeda and Theravance. RWD owns Eli Lilly and Co. stock.

\section{Dr. med. Konstantin Mechler}

Department of Child and Adolescent Psychiatry, Central Institute of Mental Health, J 5

68159 Mannheim

Germany

konstantin.mechler@zi-mannheim.de 